\title{
Preconcentration of $\mathrm{Ni}(\mathrm{II})$ on Silica gel Loaded with New Synthesized Schiff base and Their Determination by FAAS
}

\section{HAMED MASOUDINIA ${ }^{1}$, MOHAMMAD REZA NATEGHI ${ }^{1 *}$ and TAHEREH KHOSOUSI ${ }^{2}$}

\author{
1'Department of Chemistry, Yazd Branch, Islamic Azad University, Yazd, Iran. \\ ${ }^{2}$ Department of Chemistry, Neyriz Branch, Islamic Azad University, Neyriz, Iran. \\ ${ }^{*}$ Corresponding author E-mail: mnateghi@iauyazd.ac.ir
}

http://dx.doi.org/10.13005/ojc/300426

(Received: September 25, 2014; Accepted: November 03, 2014)

\begin{abstract}
A preconcentration method was developed for the determination of trace amounts of $\mathrm{Ni}(\mathrm{II})$ by atomic absorption spectrometry. The method is based on the retention of the metal cations by modified silica gel adsorbent. The adsorbed metals were then eluted with nitric acid and the $\mathrm{Ni}(\mathrm{II})$ was determined by flame atomic absorption spectrometry. The optimal extraction and elution conditions were studied. The effects of diverse ions on the preconcentration were also investigated. A preconcentration factor of 100 can easily be achieved. Calibration graph was obtained and the detection limit of the method for $\mathrm{Ni}(\mathrm{II})$ was $1.3 \mathrm{ng} \mathrm{mL}^{-1}$. The relative standard deviation (RSD) of $0.66-1.32 \%$ was obtained. The method was applied successfully to the determination of $\mathrm{Ni}(\mathrm{II})$ in water samples.
\end{abstract}

Key words: Schiff base; Solid-liquid extraction; Silica gel; Ni(II)

\section{INTRODUCTION}

Flame atomic absorption spectrometry (FAAS), is often used for the determination of trace metal ions. The direct determination of metal ions at trace level is limited due to their low concentration and matrix interferences. Therefore, a preconcentration or separation step is frequently necessary to improve the detection limit and sensitivity. For this purpose, several separation and preconcentration procedures such as solvent extraction, co- precipitation or solid phase preconcentration technique can be applied. Solid phase extraction is a sensitive, fast and economic preconcentration method for traces of analyte ions in various materials, including natural waters, ores, biological samples, etc. Of all separation-enrichment separation procedures, solid phase extraction possesses several advantages: large preconcentration factors, simplicity of phase separation and suitability for automation ${ }^{1-3}$. 
Of the many types of solid phase used in SPE, silica gel immobilized by various organic and inorganic compounds that use a metal chelating agent to remove, extract, separate and preconcentrate metal ions from different matrices display high thermal, chemical and mechanical stability ${ }^{4}$ and is less susceptible to swelling, shrinking, and microbial and radiation decay ${ }^{5-8}$. The selectivity of the modified silica gel mainly depends on the structure of the immobilized organic compound as a whole, the nature of the incorporated donor atoms $(\mathrm{O}, \mathrm{N}, \mathrm{P}$ and $\mathrm{S})$, the positioning of the functional groups along the surface of the silica, and the steric requirements of the complex formed after uptake of the desired metal ion ${ }^{9-11}$. A variety of chelating ligands have been used to modify a silica gel surface. It is then possible to immobilize new molecules with a variety of organic functions, including chelating agents ${ }^{5,12-19}$. Silica gel functionalized with 1,8dihydroxyanthraquinone ${ }^{19}, 2$-aminomethylpyridine ${ }^{20}$, p-dimethyl amino benzaldehyde, ${ }^{21}$ 4-(8-hydroxy-5quinolyazo) naphthalene, ${ }^{22}$ 2,4,6-trimorpholine1,3,5-triazin ${ }^{23}$, benzophenone-4-aminobenzoylhydrazine ${ }^{17}$, 4-amino-2-ercaptopyrimidine ${ }^{11}$, ethyl-2benzothi -azolylacetate ${ }^{24}$ have been used to enrich for metal ions, $\mathrm{Cd}(\mathrm{II}), \mathrm{Co}(\mathrm{II}), \mathrm{Cu}(\mathrm{II}), \mathrm{Ni}(\mathrm{II}), \mathrm{Pb}(\mathrm{II})$ and $\mathrm{Zn}(\mathrm{II})$. The modified silica have been used in various areas, most notably in metal ion preconcentration ${ }^{25}$, ion exchange, ${ }^{26-27}$ biotechnology ${ }^{28}$, sensors ${ }^{29}$, catalysis $^{30-32}$, pesticides removal ${ }^{33}$ and green chemistry ${ }^{34}$.

In this study, ethylendiamin-2-hydroxy-3methoxy benzaldehyde was immobilized on the surface of a silica gel to create a new solid-phase extractant. The new sorbent was successfully applied to the preconcentration and determination of $\mathrm{Ni}(\mathrm{II})$ in aqueous solutions and environmental samples.

\section{EXPERIMENTAL}

\section{Apparatus}

A Varian model AA240FS flame atomic absorption Spectrophotometer (FAAS) equipped with hollow cathode lamp (HCL) was used for determinations. The optimum conditions for FAAS are given in Table 1.

Metrohm pH meters (model 827) with a combined glass $\mathrm{pH}$ electrode, calibrated against standard buffer solutions at $\mathrm{pH} 4.0,7.0$ and 9.0, were used for $\mathrm{pH}$ measurements. All measurements were made at atmospheric temperature and pressure.

\section{Reagents and solutions}

All chemicals used were of analyticalreagent grade and all solutions were prepared with doubly distilled deionized water. Stock solutions of iron and those used for the interference study (1000 $\mathrm{mg} \mathrm{L}^{-1}$ ) were prepared by dissolving appropriate amounts of their respective pure nitrate salts (Merck) in deionized water. Working standard solutions were obtained daily by suitable stepwise dilution of the stock solutions with deionized water and shaking them just prior to use. Sodium dihydrogen phosphate $\left(\mathrm{NaH}_{2} \mathrm{PO}_{4}\right)$-disodium hydrogen phosphate $\left(\mathrm{Na}_{2} \mathrm{HPO}_{4}\right)$, hydrochloric acid $(\mathrm{HCl})$, nitric acid $\left(\mathrm{HNO}_{3}\right)$, and sodium hyroxide $(\mathrm{NaOH})$ were obtained from Merck Chemicals. In the elution work, $\mathrm{HNO}_{3} 1 \mathrm{M}$ was used to extract the adsorbed $\mathrm{Ni}$ (II) from the Schiff base-loaded silica gel. The buffer solutions in the range of $\mathrm{pH} \mathrm{2-10}$ were prepared using sodium dihydrogen phosphate $\left(\mathrm{NaH}_{2} \mathrm{PO}_{4}\right)$ and disodium hydrogen phosphate $\left(\mathrm{Na}_{2} \mathrm{HPO}_{4}\right)$. The Schiff base solution was prepared by dissolving 0.7 $\mathrm{g}$ of ethylendiamin-2-hydroxy-3-methoxy benzaldehyde in $50 \mathrm{~mL}$ of aceton (Merck). Silica gel (bead size, 20-40 mesh) taken from Merck. All glass apparatus were washed with acid after use.

\section{Preparation of Schiff base-loaded silica gel}

Modified silica gel was prepared as follows: $0.7 \mathrm{~g}$ of Schiff base was suspended in 50 $\mathrm{mL}$ of aceton. Then, the prepared Schiff base solution was added to $35 \mathrm{~g}$ silica gel and the mixture was stirred to evaporate the acetone. The modified silica gel was dried and the prepared powder was ground and was kept for further studies.

\section{Extraction procedure}

The $\mathrm{pH}$ of the $\mathrm{Ni}(\mathrm{II})$ solution $(700 \mathrm{~mL} ; 12.5$

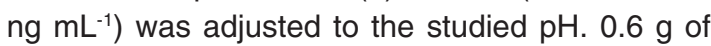
dried modified silica gel was added to $\mathrm{Ni}$ (II) solution. The mixture was mechanically stirred for $60 \mathrm{~min}$ and filtered through a filter paper by using a vacuum pump. For elution of the adsorbed $\mathrm{Ni}(\mathrm{II})$ on the modified silica gel, $7.0 \mathrm{~mL}$ of $\mathrm{HNO}_{3} 1 \mathrm{M}$ was used. The clear solution was measured using FAAS. The blank solutions were carried out in the same way. 


\section{RESULTS AND DISCUSSION}

Modified silica gel has been used to preconcentrate $\mathrm{Ni}(\mathrm{II})$ after a chelating agent was adsorbed or bonded chemically on silica gel surface. Extraction of $\mathrm{Ni}(\mathrm{II})$ is probably due to proton exchange mechanism. Therefore for selection of desorption solvent, acidic solution with different concentration were used. The parameters that are thought to affect the preconcentration and measurement steps in the analytical scheme were examined using the model solutions of $12.5 \mathrm{ng} \mathrm{mL}$ 1. The effect of each parameter was tested three times.

\section{Metal extraction}

The ability of modified silica gel to adsorb $\mathrm{Ni}($ II) from aqueous solutions was studied by varying different parameters namely the $\mathrm{pH}$, weight ratio of Schiff base/silica gel, stirring time, and type and concentration of eluent. The solid-liquid extraction of a metal ion may be described by the following equilibrium:

$$
\mathrm{M}^{\mathrm{n}+}+\mathrm{nHL} \leftrightarrow \mathrm{ML}_{\mathrm{n}}+\mathrm{nH}^{+}
$$

The extraction percentage of a metal may be expressed as:

$$
E(\%)=\frac{[M] a q, i-[M] a q, e}{[M] a q, i}
$$

where $[\mathrm{M}]_{\mathrm{aq}, \mathrm{i}}$ and $[\mathrm{M}]_{\mathrm{aq}, \mathrm{e}}$ are the concentrations in the aqueous phase before and after extraction, respectively ${ }^{35}$.

\section{Effect of the $\mathrm{pH}$ on recovery}

The influence of $\mathrm{pH}$ on recovery was studied because the hydrogen-ion concentration plays an important role in the preconcentration of metals by SPE because it significantly affects the metal-ligand complex formation. The model $\mathrm{Ni}$ solutions was preconcentrated using various $\mathrm{pH}$ values ranging from 2 to 10 . The obtained recoveries are given in Fig. 1. It was seen that the maximum recoveries (up to $95 \%$ ) were found in the $\mathrm{pH}>8.0$. Therefore, for subsequent studies, the $\mathrm{pH} 8.0$ was used.
Test solutions were buffered in order to have stable $\mathrm{pH}$ values and avoid time-consuming dropwise addition of acid or base to obtain the desired $\mathrm{pH}$. The influence of buffer was carried out by keeping all other experimental variables constant. The results showed that in the presence of buffer the recoveries were lower than aqueous solution (Figure 2). Thus all experiments were carried out in aqueous solution.

\section{Effect of the weight ratio of schiffbase/silica gel on recovery}

In order to determine the optimum weight ratio of schiffbase/silica gel, the recoveries of model solution of $\mathrm{Ni}(\mathrm{II})$ at the optimum $\mathrm{pH}$ (8.0) were examined using different weight ratio of 0.010 , $0.015,0.020,0.025$, and 0.030 Schiff base/silica

Table 1: Operating parameters for flame atomic absorption spectrometry

\begin{tabular}{lc}
\hline Method Parameters & Type or Value \\
\hline $\mathrm{Ni}(\mathrm{II})$ Wavelength (nm) & 232.0 \\
Lamp Current ( $\mathrm{mA})$ & 4 \\
Slit Width (nm) & 0.2 \\
Flame type & Air / Acetylene \\
Optimum working range (ppm) & $0.1-20$ \\
\hline
\end{tabular}

Table 2: Effect of interfering ions on the recovery of $50 \mathrm{ng} \mathrm{mL}^{-1} \mathrm{Ni}(\mathrm{II})$ in water samples using SPE-FAAS method

Ion Mole ratio Recovery(\%)

$\begin{array}{lcc}\mathrm{Ca}^{2+} & 500 & 98 \\ \mathrm{Mg}^{2+} & 500 & 101 \\ \mathrm{Na}^{+} & 500 & 99 \\ \mathrm{~K}^{+} & 500 & 98 \\ \mathrm{Hg}^{2+} & 500 & 93 \\ \mathrm{Fe}^{3+} & 500 & 98 \\ \mathrm{Ag}^{+} & 500 & 95 \\ \mathrm{Al}^{3+} & 500 & 94 \\ \mathrm{Fe}^{2+} & 200 & 97 \\ \mathrm{Mn}^{2+} & 200 & 95 \\ \mathrm{CH}_{3} \mathrm{COO}- & 200 & 98 \\ \mathrm{NH}_{4}{ }^{+} & 100 & 97 \\ \mathrm{SO}_{4}^{2-} & 100 & 95 \\ \mathrm{Co}^{2+} & 15 & 96\end{array}$


Table 3: Analytical results of $\mathrm{Ni}(\mathrm{II})$ determination in spiked natural water samples with the SPE-FAAS method $(n=3)$

\begin{tabular}{lccc}
\hline Sample & \multicolumn{2}{c}{$\mathbf{N i}^{2+}\left(\mathbf{n g ~ m L}^{-1}\right)$} & Recovery \\
\cline { 2 - 3 } & Added & Determined & (\%) \\
\hline \multirow{2}{*}{ Tap Water } & - & 0 & - \\
& 20 & 1860 & 93 \\
60 & 5700 & 95 & \\
Well Water & - & 0 & - \\
& 20 & 1920 & 96 \\
& 60 & 6180 & 103 \\
\hline
\end{tabular}

gel. It is seen from Fig. 3 that the recoveries increase up to $95 \%$ with weight ratio of 0.020 Schiff base/ silica gel and have very little change by adding up to 0.030 . Thus, weight ratio 0.020 was used in contact with $700 \mathrm{~mL} \mathrm{Ni}$ (II) solution in the subsequent studies. This amount was increased according to the volume of $\mathrm{Ni}(\mathrm{II})$ solution, proportionally.

\section{Effect of the stirring time on recovery}

The kinetics of the $\mathrm{Ni}(\mathrm{II})$ sorption and desorption were investigated in a batch system. It was found that the stirring time of $60 \mathrm{~min}$ is sufficient for sorption of $\mathrm{Ni}(\mathrm{II})$ on silica gel (Fig. 4). The preconcentration procedure was applied to the model solutions using different stirring times with all other optimum conditions. It was found that the stirring time of $60 \mathrm{~min}$ was sufficient for maximum recovery in the first step (up to 95\%). This stirring time is shorter compared to other studies where preconcentration time as long as 2-4 $\mathrm{h}$ was required for maximum recovery in the literature. So, the stirring time of $60 \mathrm{~min}$ was used for all studies.

\section{Effect of the type and concentration of eluent on recovery}

Extraction of $\mathrm{Ni}(\mathrm{II})$ is probably due to proton exchange mechanism. Therefore for elution purpose, acidic solutions with different concentration were examined. The efficiency of the two eluents $\left(\mathrm{HCl}\right.$ and $\left.\mathrm{HNO}_{3}\right)$ were studied by taking different concentrations $(0.5-4.0 \mathrm{M})$. It was found that $7 \mathrm{~mL}$ of $1 \mathrm{M} \mathrm{HNO}_{3}$ was sufficient for maximum recovery (up to $95 \%$ ) of $\mathrm{Ni}$ (II) (Fig. 5). Therefore, $7.0 \mathrm{~mL}$ of $1 \mathrm{M}$ $\mathrm{HNO}_{3}$ was used for complete desorption of the nickel. $\mathrm{HCl}$ van be reach to this recovery at $4 \mathrm{M}$ that indicated the $\mathrm{HNO}_{3}$ is stronger eluent than $\mathrm{HCl}$.

\section{Effect of sample volume on recovery}

One of the most important parameters for obtaining high preconcentration factors is the sample volume. The effect of sample volume on the recovery of $\mathrm{Ni}(\mathrm{II})$, was investigated in the range of 250-1500 mL volume of the model solutions containing $12.5 \mathrm{ng} \mathrm{mL}^{-1}$ at $\mathrm{pH}$ 8.0. The results in Figure 6 show that $\mathrm{Ni}(\mathrm{II})$ up to volume of $1000 \mathrm{~mL}$ were recovered quantitatively. When the volume of final solution was $7 \mathrm{~mL}$, the preconcentration factors for Co(II) was found to be 143.In addition, volume of $1000 \mathrm{~mL}$ was used for determination of sorption capacity (Fig. 6). The sorbtion capacity was 14600 ng per g modified silica gel.

\section{Effect of interfering ions}

The effect of some major components present in natural samples such as $\mathrm{Na}(\mathrm{I}), \mathrm{K}(\mathrm{I}), \mathrm{Ca}(\mathrm{II})$, $\mathrm{Mg}(\mathrm{II})$, and $\mathrm{SO}_{4}{ }^{2 "}$ ions on the recoveries of analyte ions was investigated by the proposed method. The interfering elements were added to the model sample solutions as their nitrate or chloride salts. $700 \mathrm{~mL}$ of model solutions containing $50 \mathrm{ng} \mathrm{mL}^{-1}$ and the matrix ions were prepared and the proposed procedure was applied. Table 2 shows the effect of the interfering ions on the recoveries of $\mathrm{Ni}(\mathrm{II})$. In the medium containing 500 times of alkaline and alkaline earth metals, the signal of $\mathrm{Ni}(\mathrm{II})$ was not affected from matrix components, the recovery values for cobalt are not quantitative.

\section{Analytical performance}

The calibration curve was observed to be linear at the concentration range of $5-100 \mathrm{ng} \mathrm{mL}^{-1}$ by taking $700 \mathrm{~mL}$ solution to final volume of $7.0 \mathrm{~mL}$ of $1 \mathrm{M} \mathrm{HNO}_{3}$ (using $600 \mathrm{mg}$ modified silica gel). The equations of the curves are as follows (Fig. 7): 


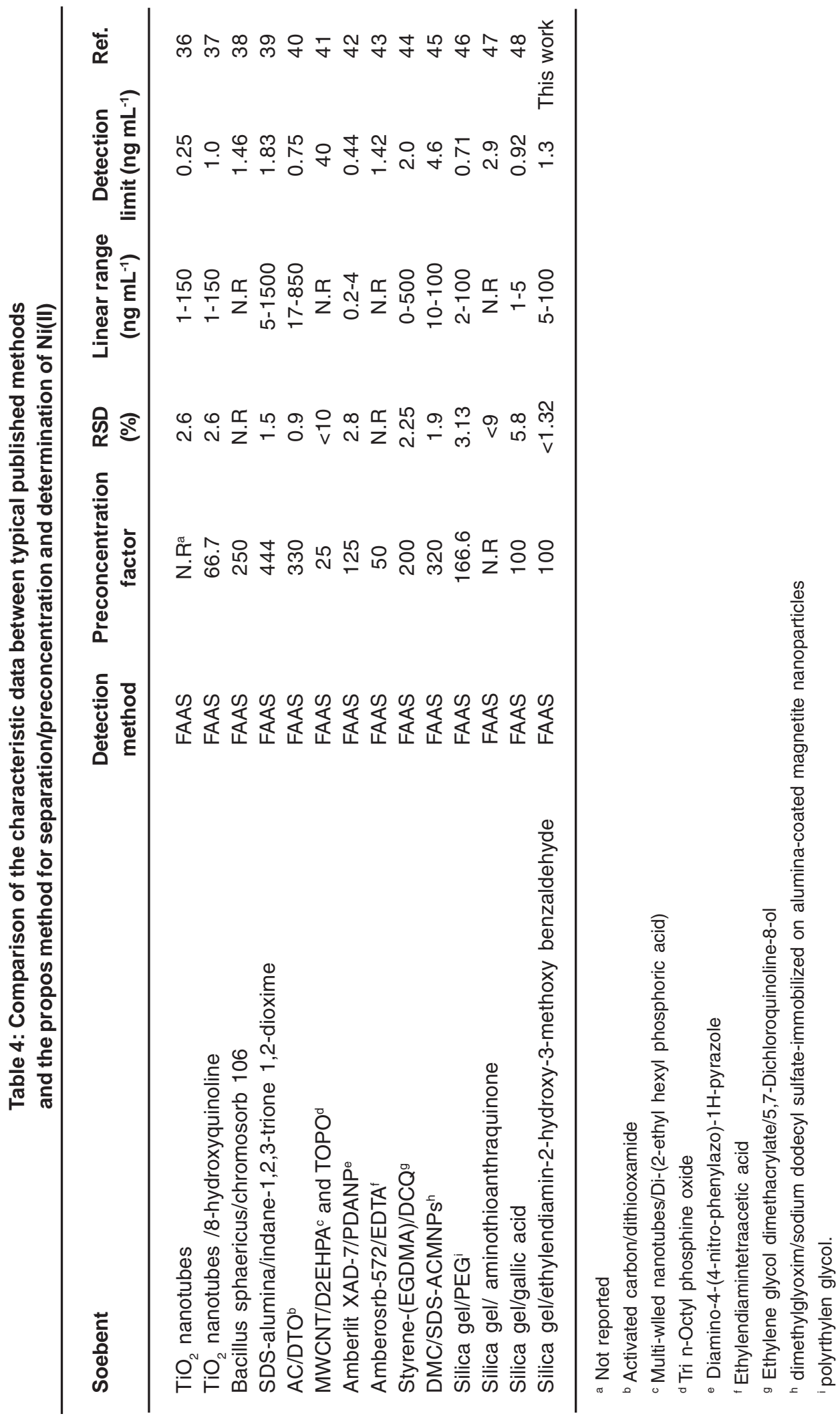




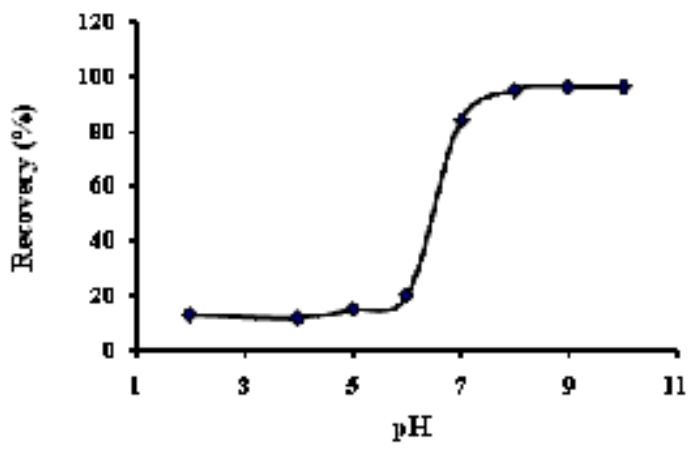

Fig. 1: Influence of sample pH on the recovery percentage of $\mathrm{Ni}(\mathrm{II})$ in aqueous solution.

Experimental conditions: [Ni] $=12.5 \mathrm{ng} \mathrm{mL}^{-1}$, [Schiff base/silica gel] $=0.02$, stirring time $=60$ min, $\mathrm{HNO}_{3} 1 \mathrm{M}$ as eluent

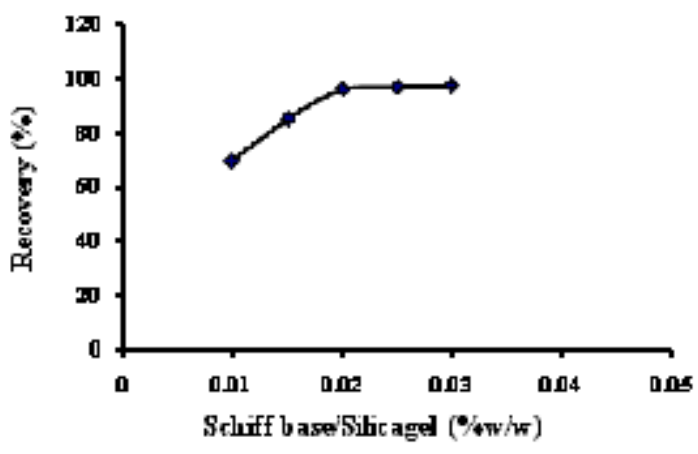

Fig. 3: Influence of schiffbase/silica gel weight percentage on the recovery percentage of $\mathrm{Ni}(\mathrm{II})$.

Experimental conditions: [Ni]= $12.5 \mathrm{ng} \mathrm{mL}^{-1}$, $\mathrm{pH}=8$, stirring time $=60 \mathrm{~min}, \mathrm{HNO}_{3} 1 \mathrm{M}$ as eluent

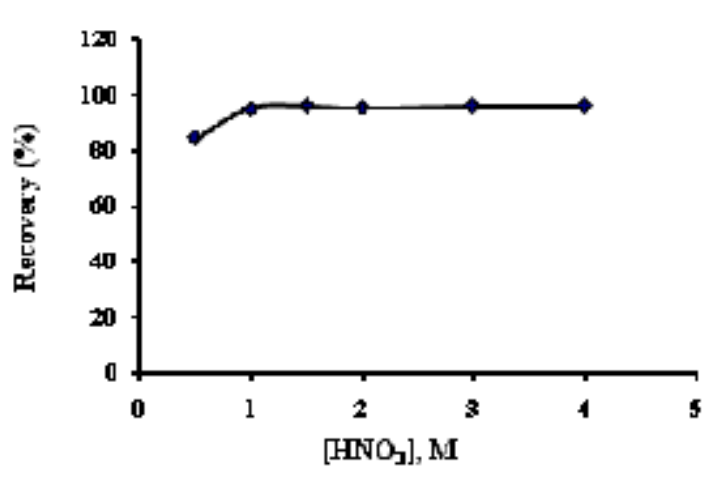

Fig. 5: Influence of eluent concentration on the recovery percentage of $\mathrm{Ni}$ (II). Experimental conditions: [Ni] $=12.5 \mathrm{ng} \mathrm{mL}^{-1}$, [Schiff base/silica gel $]=0.02, \mathrm{pH}=8$, stirring time $=60 \mathrm{~min}$.

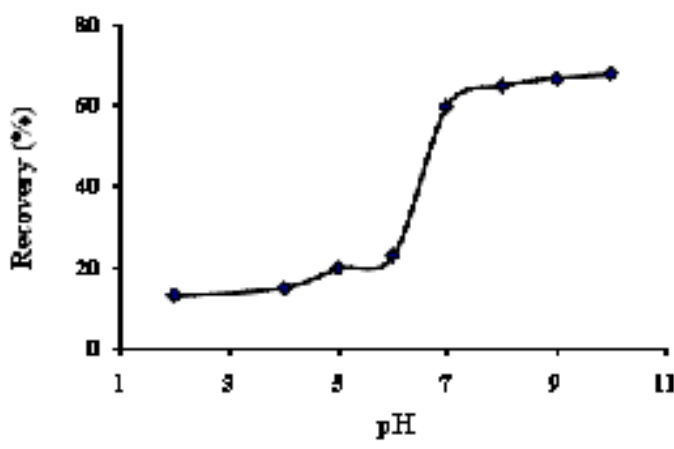

Fig. 2: Influence of sample pH on the recovery percentage of $\mathrm{Ni}(\mathrm{II})$ in phosphate buffer $(0.01 \mathrm{M})$ solution. Experimental conditions: [Ni]=12.5 ng $\mathrm{mL}^{-1}$, [Schiff base/silica gel] $=0.02$, stirring time $=60 \mathrm{~min}, \mathrm{HNO}_{3} 1 \mathrm{M}$ as eluent

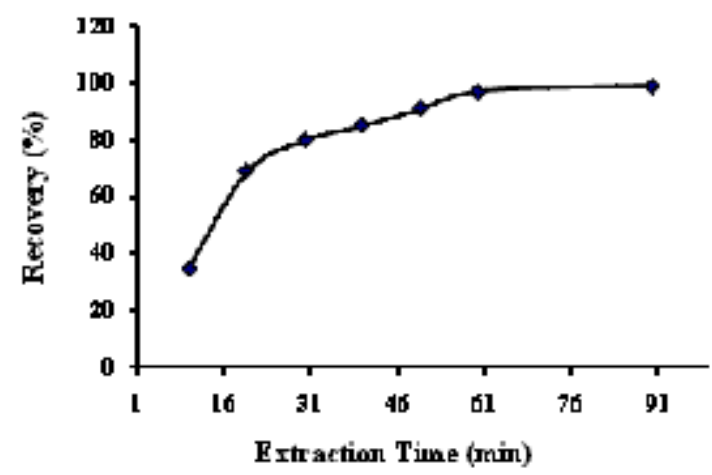

Fig. 4: Influence of stirring time on the recovery percentage of $\mathrm{Ni}(\mathrm{II})$. Experimental conditions: $[\mathrm{Ni}]=\mathbf{1 2 . 5} \mathrm{ng} \mathrm{mL}^{-1}, \mathrm{pH}=\mathbf{8}$, [Schiff base/silica gel] $=0.02, \mathrm{HNO}_{3} 1 \mathrm{M}$ as eluent

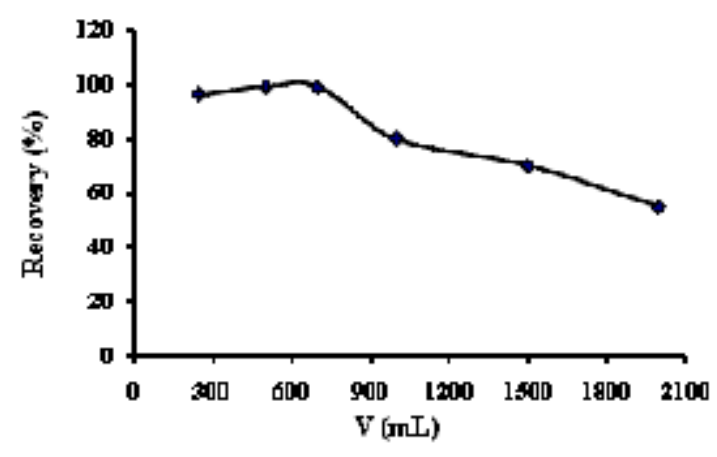

Fig. 6: Influence of volume of $\mathrm{Ni}(\mathrm{II})$ on the recovery percentage of $\mathrm{Ni}(\mathrm{II})$. Experimental conditions: [Ni]=12.5 ng mL $\mathrm{ng}^{-1}$, [Schiff base/silica gel] $=0.02$, $\mathrm{pH}=8$, stirring time $=60 \mathrm{~min}, \mathrm{HNO}_{3} 1 \mathrm{M}$ as eluent 


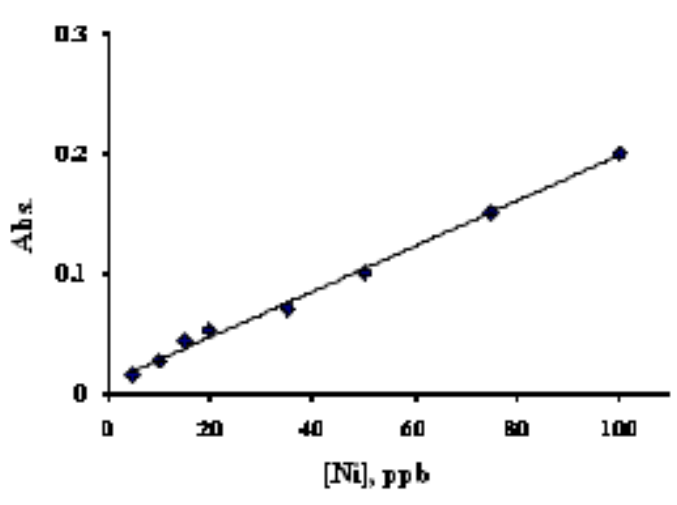

Fig. 7: Calibration curve for different concentration on $\mathrm{Ni}(\mathrm{II})$. Experimental conditions: [Schiff base/silica gel] $=0.02, \mathrm{pH}=\mathbf{8}$, stirring time $=60 \mathrm{~min}, \mathrm{HNO}_{3} 1 \mathrm{M}$ as eluent, $[\mathrm{Ni}]=5,10,15,20,35,50,75,100 \mathrm{ng} \mathrm{mL}^{-1}$.

$$
Y=0.0103 X+0.0019, R^{2}=0.9965
$$

The preconcentration factor of 100-times was required due to $\mathrm{Ni}(\mathrm{II})$ concentration as low as $12.5 \mathrm{ng} \mathrm{mL}^{-1}$ in water. Relative standard deviations (RSD) were $1.32,0.6$, and $1.01 \%$ for $700 \mathrm{~mL}$ of 5 , 10 , and $15 \mathrm{ng} \mathrm{mL}^{-1}$ of $\mathrm{Ni}(\mathrm{II})$ solution respectively. The detection limit (LOD) defined as three times the standard deviation of the blank was $1.3 \mathrm{ng} \mathrm{mL}^{-1}$.

In addition, the accuracy of the method was studied by examining the recoveries of $\mathrm{Ni}$ (II) from mineral water samples fortified with this element. From the results of Table 3, it was found that up to
$90 \%$ of the $\mathrm{Ni}(\mathrm{II})$ added to water samples was recovered.

\section{CONCLUSION}

The preconcentration method described by using Schiff base-loaded silica gel for the determination of $\mathrm{Ni}(\mathrm{II})$ in water samples has a good accuracy, repeatability, and sensitivity. The sensitivity of FAAS was increased up to 100-times using the optimized method. So, the detection limit was found to be $1.3 \mathrm{ng} \mathrm{mL}^{-1}$ when a sample volume of $700 \mathrm{~mL}$ was preconcentrated to a final volume of $7.0 \mathrm{~mL}$. The RSD of the method was < 1.32. A comparison of the characteristic data between some existing reported methods and the proposed method for separation/preconcentration and determination of $\mathrm{Ni}(\mathrm{II})$ by FAAS ${ }^{36-48}$ is given in Table 4. As Table 4 shows, the proposed method exhibits a comparable capacity factor, a low detection limit and a wide linear range, as well as being a convenient, safe, simple, and inexpensive method for the determination of trace quantities of $\mathrm{Ni}(\mathrm{II})$ in real samples giving satisfactory results.

\section{ACKNOWLEDGEMENTS}

The authors wish to thank Dr. Masoumeh Tabatabaie for her helps. The authors are also wish to thank the Chemistry Department of Islamic Azad University of Neyriz and Islamic Azad University of Yazd for financial support.

\section{REFERENCES}

1. Lee, S. H.; Choi, H. S.; B. Kor. Chem. Soc. 2003, 24, 1705.

2. Kara, D.; Tekin, N.; Microchim. Acta. 2005, 149, 193.

3. Her, G.; Choi, H. S.; J. Korean Chem. Soc. 2005, 49, 145.

4. Sales J A A, Faria F P, Prado A G S and Airoldi C Polyhedron 2004, 23, 719.

5. Vansant, E. F.; Van der Voort, P.; Vrancken, K. C. Stud. Surf. Sci. Catal. 1995, 93, 149.

6. Zaporozhets O, Petruniock N, Bessarabova O and Sukhan V Talanta 1999, 49, 899.

7. Prado A.G.S, and Airoldi C, Anal. Chim. Acta 2001, 432, 201.

8. Kim J.S, and Yi J, Sep. Sci. Technol. 1999,
34, 2957.

9. Camel V, Spectrochim. Acta Part B 2003, 58, 1177.

10. Zhang L, Chang $X$, Zhai $Y$, He Q, Huang X, $\mathrm{Hu}$ Z, and Jiang N, Anal. Chim. Acta 2008, 629, 84

11. Pereira A.S, Ferreira G, Caetano L, Martines M.A U, Padilha P.M, Santos A, and Castro G.R, J. Hazard. Mater. 2010, 175, 399.

12. Alcantara I.L, Roldan P.S, Castro G.R, Moraes F.V, Silva F.A, Padilha C.C.F, Oliveira J.D, and Padilha P.M, Anal. Sci. 2004, 20, 1029.

13. Hatay I, Gup R, and Ersoz M, J. Hazard. Mater. 2008, 150, 546. 
14. Gao B, An F, and Liu K, Appl. Surf. Sci. 2006, 253, 1946.

15. Castro G.R, Cristante V.M, Padilha C.C.F, Jorge S.M.A, Florentino A.O, Prado A.G.S, and Padilha P.M, Microchim. Acta 2008, 160, 203.

16. Cestari A.R, Viera E.F.S, Nascimento A.J.P, de Oliveira F.J.R, Bruns R.E, and Airoldi C.J, Colloid Interface Sci. 2001, 241, 45.

17. Gubbuk I.H, Gup R, and Ersoz M, J. Colloid Interface Sci. 2008, 320, 376.

18. Zhang $Y$, Qu R, Sun C, Chen H, Wang C, Ji $C$, Yin $P$, Sun $Y$, Zhang $H$, and Niu $Y, J$. Hazard. Mater. 2009, 163, 127.

19. Kelode, S.R., Mandlik, P.R., Aswas A.S., Orient J. Chem., 2011, 27(3), 1053-1062.

20. Goswami A, and Singh A.K, Talanta 2002, 58, 669.

21. Sales J.A, Faria F.P, Prado A.G, and Airoldi C, Polyhedron 2004, 23, 719.

21. Cui Y, Chang X, Zhu X, Luo H, Hu Z, Zou X, and $\mathrm{He}$ Q, Microchemical J. 2007, 87, 20.

23. Chang $X$, Luo H, Cui Y, Zhu X, Zhai Y, Hu, and He, J. Mol. Struct. 2008, 891, 45.

24. Madrakian T, Zolfigol M.A, and Solgi M, J. Hazard. Mater. 2008, 160, 468.

25. Aeungmaitrepirom W, Ngeontae W, and Tuntulani T, Anal. Scien. 2009, 25, 1477.

26. Padilha P.M, Gomes L.A.M, Padilha C.C.F, Moreira J.C, and Dias Filho N.L, Anal. Lett. 1999, 32, 1807.

27. Espinola J.G.P, Oliveira, S.F, Lemus W.E.S, Souza A.G, Airoldi C, and Moreira J.C A, Colloids Surf. A Physicochem. Eng. Aspects 2000, 166, 45.

28. Goswami A, and Singh A.K, Anal. Chim. Acta 2002, 454, 229.

29. Kallury K.M.R, Lee W.E, and Thompson M, Anal. Chem. 1993, 65, 2459.

30. Fujiwara S.T, Pessoa C.A, and Gushikem Y,
Anal. Lett. 2002, 35, 1117.

31. Fisher H.E, King S.A, Miller J.B, Ying J.Y, Benzinger J.B, and Schwartz J, Inorg. Chem. 1991, 30, 4403.

32. Guo Y, Hu C, Jiang C, Yang Y, Jiang S, Li X, and Wang E, J. Catal. 2003, 217, 141.

33. Valkenberg M.H, and Holderich W.F, Catal. Rev. 2002, 44, 321.

34. Prado A.G.S, and Airoldi C, Fresenius J. Anal. Chem. 2001, 371, 1028.

35. Clark J.H, and Macquiarrie D.J, Chem. Commun. 1998, 5, 853.

36. Bouazza D, Tayeb A, Sassi M, Benguedach A, and Boos A, Orient. J. Chem. 29 (3) 991.

37. Zhao X.N, Shi Q.Z, Xie G.H, Zhou Q.X, Chin. Chem. Lett. 2008, 19, 865.

38. Zhou Q.X, Zhao X.N, Xiao J.P, Talanta 2009, 77, 1774.

39. Tuzen M, Soylak M, J. Hazard. Mater. 2009, 164, 1428.

40. Hosseini M, Dalali N, Karimi A, Dastanra K, Turk. J. Chem. 2010, 34, 805.

41. Ghaedi M, Ahmadi F, Soylak M, J. Hazard. Mater. 2007, 147, 226.

42. Vellaichamy S, Palanivelu K, J. Hazard. Mater. 2011, 185, 1131.

43. Ciftci $\mathrm{H}$, Yalcin $\mathrm{H}$, Eren E, Olcucu A, Sekerci M, Desalination 2010, 256, 48.

44. Baytak S, Tu“ rker A.R, J. Hazard. Mater2006, 129, 130.

45. Praveen R.S, Daniel S, Rao T.P, Talanta 2005, 662, 513.

46. Karimi M.A, Kafi M, Arabian J. Chem. (2013) In press.

47. Pourreza N, Zolgharnein J, Kiasat A.R, Dastyar T, Talanta 2010, 81, 773.

48. Ngeontae W, Aeungmaitrepirom W, Tuntulani T, Talanta 2007, 71, 1075.

49. Xie F, Lin X, Wu X, Xie Z, Talanta 2008, 74, 836. 